\title{
Thinking outside the Chinese Box: David Mitchell and Murakami Haruki's subversion of stereotypes about Japan
}

\author{
Chikako Nihei \\ University of Sydney
}

\begin{abstract}
Japan has often been portrayed by orientalist stereotypes, as famously framed by Edward Said, that were mainly constituted within Europe and North America. There are two distinct streams of orientalist discourse around Japan: traditional Orientalism and techno-Orientalism. Here the West speaks of the Other/the non-West rather than allowing it to speak for itself. In regards to the discourse of 'Otherness', another interesting phenomenon is Japan's self-Orientalising: through the internalisation of the Western Orientalist discourse, Japan identifies itself and constructs its own subjectivity.
\end{abstract}

In his literary works, the author David Mitchell attempts to subvert the conventional orientalist approach to describe Japan while concurrently maintaining his position as a British observer. He makes use of Western perspectives to cater to his Western readers' preference for Japan's traditional and cultural elements, and yet at the same time attempts to subvert stereotypes. Mitchell's approach is reminiscent of Japanese author Murakami Haruki's use of both 'Japaneseness' and 'un-Japaneseness' in his works. Mitchell also learnt the importance of the use of the subjective narrative voice from Murakami. In this article, I examine how David Mitchell, as a western author, attempts to go beyond orientalist stereotypes, and how his writing is influenced by Murakami Haruki.

\section{Keywords}

David Mitchell, Murakami Haruki, Orientalism, stereotypes, subjectivity

\section{The Orientalisation of Japan}

There have been a great number of non-Japanese authors and scholars who have written on Japan from an outsider perspective, claiming to narrate Japan objectively. Such supposed objectivity, however, has often been informed by an Orientalist approach. Orientalism, famously framed by Edward Said, is a concept to account for the relation between the East and the West, mainly focusing on Western perspectives. Richard H. Minear points out three aspects of Said's theory of Orientalism: 'its use of 
the abstractions "Oriental" and "European," its prejudice in favour of the latter, and the relation in Orientalist thinking between past "Oriental" greatness and present "Oriental" degradation.' Minear explains that Said portrays the 'European' and the West as 'a known quantity, familiar and comfortable', 'rational, virtuous, mature, "normal," 'developed, humane, superior,' while the 'Oriental' is 'strange', 'irrational, depraved (fallen), childlike, "different," 'aberrant, undeveloped, inferior.' In other words, Orientalism projects an image of European (and, by extension, Western) superiority, contrasted with, and built upon, Eastern inferiority. While Edward Said formulated the notion of Orientalism mainly in relation to the Middle East, analysing Europe's representation of its closest non-Western other, the notion has been usefully applied to European and North American approaches to Japanese culture.

Scholars such as Basil Hall Chamberlain, George B. Sansom and Edwin O. Reischauer explained Japan within the context of a clearly defined East/West dichotomy. In his examination of the works of these three scholars, Richard Minear outlines the history of Western Orientalisation of Japan since 1880. According to Minear, Chamberlain divided the world into West and East, constantly writing about 'we' and 'they', and putting Japan in the same category as Korea and China. Similarly, from the late 1920s, George Samson emphasised the value of the West and taught Japanese culture within Asian studies courses, once again stressing a pan-Asian, Orientalist perspective. Edwin O. Reischauer, while describing Japan and other 'Oriental' countries as simply different, rather than inferior, also emphasised the importance of Western modernisation, arguing that such 'difference' should be reduced through the adoption of Western ways on the part of Japan. ${ }^{3}$

Thus Japan has often been understood within the context of traditional Orientalism, focusing on its exotic features and aestheticising its traditional culture and history. Western images of Japanese tradition clustered around two main approaches: they either emphasised Japan's feminine quality and its elegance, or stressed the inherently violent nature of its society. The combination of the two is aptly encapsulated by Ruth Benedict in the image of a Japan divided between 'the chrysanthemum and the sword' in her book by the same title. Rebecca Suter explains the West's aestheticising of Japan: '[a]dmiration for Japanese art, tradition, and beauty often conceals a mechanism of defense, an attempt to reify the ethnic Other in order to disempower it, and to project an image of backwardness against which the modernity of the West can be measured'. Such images of 'backwardness', which were reinforced through the aestheticisation of

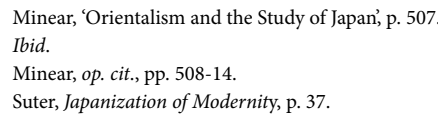


Japan's history and culture, contributed to construct an image of Japan as disempowered, while more violent images of samurai and 'warrior spirit', were used to present the country as a threat to the West.

\section{From Orientalism to Techno-Orientalism}

More recently, after Japan's successful modernisation, new stereotypes have emerged that link Japan with high-tech imagery, centring on its technological and economical success. David Morley and Kevin Robins define this phenomenon as 'techno-Orientalism, and state that ' $[t]$ he technological and futurological imagination has come to be centred here; the abstract and universalizing force of modernization has passed from Europe to America to Japan. ${ }^{5}$

In one sense, 'techno-Orientalism' is a celebration of Japan's successful modernisation. For instance, in North American science fictional works such as Neuromancer and Blade Runner, we find various high-tech images of contemporary Japan. Yoshimoto Mitsuhiro points out that '[i]n William Gibson's Neuromancer, the future world does not seem to be able to function without things Japanese.' 6 The enhancement of Japan's high-tech image is a sign of the importance of Japan's position within the representation of modernisation. To quote Iwabuchi Kōichi, 'Japan's "economic miracle"... changed western views towards Japan, because Japan has emerged as a strong competitor... As a threat to western power, the future of Japan's economic power was the main focus of concern in "the West"?

However, Japan's economic success was also perceived, and represented, as a threat to the West. According to Morley and Robins, in the 1980s the United States began to hold 'an anxiety about exposure to, and penetration by, Japanese culture', as a consequence of the global dominance of Japanese companies such as Sony and Matsushita. ${ }^{8}$ To quote Robert Reich, ' $[\mathrm{m}]$ ost American high-tech companies are well along in the process of losing their uniquely American identities' because of the Japanese 'invasion' of the American industry and of the American dependence on Japanese technology. ${ }^{9}$ American technology used to be 'viewed as something that can be uniquely American... within the nation's borders. ${ }^{10}$ However, such borders become increasingly ambiguous as Europe and the United States feel the pressure of Japan permeating their culture.

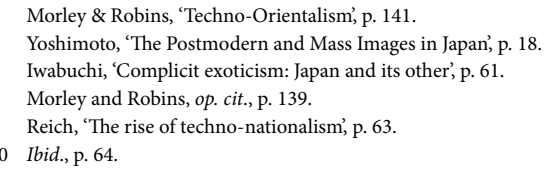


'Techno-Orientalism' constitutes a response to this perceived anxiety, and attempts to relegate Japan once again in a subaltern position by spreading an image of its people and culture as dehumanised. Stressing futuristic images such as robots and videogames makes Japanese people appear as lacking in emotion. To quote Morley and Robins:

The association of technology and Japaneseness now serves to reinforce the image of a culture that is cold, impersonal and machine-like, an authoritarian culture lacking emotional connection to the rest of the world... This recreates in a new dimension the image of the Japanese as inhuman... Within the political and cultural unconscious of the West, Japan has come to exist as the figure of empty and dehumanized technological power. ${ }^{11}$

This is reminiscent of older images of Japan as a country of violent samurai. Especially for the United States, which feels the crisis of the erosion of its borders, 'to see Japan as the enemy now is one way to bring the identity of that soul back into focus. ${ }^{12}$

\section{From Orientalism to Self-Orientalism}

Both traditional Orientalism and techno-Orientalism thus constitute attempts to differentiate Japan from Western countries in order to relegate it to a subaltern position, providing Western audiences with fixed images of Japan as backward, violent, and inhuman. In the framework of Orientalism, Western countries have treated Japan as just an object of knowledge, constantly speaking for their subaltern rather than allowing it to speak for itself. The main problem with this approach is its unidirectional dimension, the fact that this movement is almost invariably from the West to the East. Because of the easy access stereotypes offer, people tend to take them at face value without questioning their accuracy. Once people form an impression of a culture or a nation, they will believe that they have enough knowledge. Thus stereotypes limit people's knowledge by preventing them from investigating it further.

Such stereotypes however are not fixed; they also change over time, according to historical circumstances. In the specific case of Japan, Sheila Johnson thus reflects on its North American representations: ' $[w]$ hen relations are good, as at the beginning of the twentieth century or in the 1960s, aestheticized representations tend to prevail, whereas when relations become difficult, as during the war, or following the trade tensions of the 1980s, warrior Japan is the dominant image. ${ }^{13}$ While the power of stereotypes is

11 Morley and Robins, op. cit., pp. 154-5.

12 Ibid., p. 140.

13 Suter, op. cit., p. 37. 
unquestionable, such evolution and oscillation also make room for a greater degree of agency on the part of single authors, who might be able to influence the audience's perception of a culture.

As Said points out, the construction of Orientalism proceeds from the attempt to speak for the Other. Applying Said's theory to the case of Japan, Minear argues that 'the pursuit of knowledge involves the attempt to appropriate the reality of subject, and is therefore aggressive; the subject is reduced, almost by necessity, to the status of object.' ${ }^{14}$ To speak for the Other often results in ignoring its subjectivity. In a similar way, Iwabuchi explains that the Western way of picturing Japan is the expression of 'a western desire to enclose the otherness of Japan with "knowable" mysteries in order to control it'. ${ }^{15}$ To speak for the Japanese 'Other' thus enabled the West to control it.

In the post-war period, another interesting phenomenon emerged: the so-called Nihonjinron, literally 'the theory of the Japanese', a series of works variously describing and constructing the idea of 'Japanese uniqueness." ${ }^{16}$ In her study of Nihonjinron discourse, Lynn Revell explains that 'the so-called Japanese obsession with their own uniqueness exists more clearly in the eyes of the West than in Japan itself'. ${ }^{17}$ The Western stress on Japanese uniqueness in order to see Japan as the Other is reminiscent of Western Orientalist discourse and its projection of an irreducible difference. However, the discourse of Nihonjinron appropriates such rhetoric in order to construct a sense of national identity for the Japanese. To quote Revell, 'Japanese are consistently encouraged to believe not only that they are different from every other people, but that it is difference which has made Japan a great nation'. ${ }^{18}$ Through the internalisation of the Western Orientalist discourse, Japan identifies itself and constructs its own subjectivity. On one level, it would appear that through the discourse of Nihonjinron the 'subaltern' Japan can finally speak for itself, without relying on Western scholars speaking for it. However, as Revell notes, for this purpose Japanese thinkers employed intellectual tools created in the West. Insofar as Japan speaks for itself within a Western discourse, this results in a form of 'self-Orientalisation'.

In this regard, Naoki Sakai presents the mutually interdependent relationship between the West, mainly the United States, and Japan as one of fundamental complicity. While the West constructs a self-image of rationality and superiority through its relationship with Japan, Japan also defines its own position by emphasising

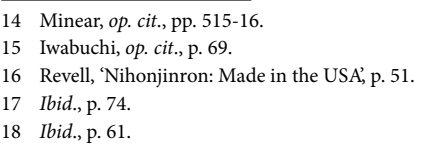


its own geographical and cultural uniqueness. Sakai states that 'Japan's uniqueness and identity are provided insofar as Japan stands out as a particular object in the field of the West... Japan becomes endowed with and aware of its "self" only when it is recognized by the West. ${ }^{19}$

The other element that is peculiar about the Japanese case is its own imperialist project in Asia, which was predicated upon a rejection of Western colonialism while at the same time incorporating some of its main features. According to Sakai, through the construction of the so-called Great East Asian Co-prosperity Sphere, Japan attempted to 'change the world so that the Japanese would occupy the position of the center and of the subject which determines other particularities in its own universal terms. ${ }^{20}$ Sakai adds that ' $[\mathrm{u}]$ niversalism and particularism endorse each other's defect in order to conceal their own; they are intimately tied to each other in their accomplice. In this respect, a particularism such as nationalism can never be a serious critique of universalism, for it is an accomplice thereof' ${ }^{21}$

From the works of Chamberlain in the early twentieth century all the way to the 1980s, such patterns of Orientalism and self-Orientalism have been the dominant mode of representations of Japan. As a complicit self-Other relationship between the West and Japan and between Japan and other Asian countries demonstrates, to speak for an Other on one's own terms often results in a pursuit of self-interest. In more recent years, however, we can also witness representations of Japan that are more nuanced and less stereotypical. I will now examine how a British author, David Mitchell attempts to go beyond these stereotypes in his novels. I also include an examination of the influence of a Japanese author, Murakami Haruki, on Mitchell's work.

\section{David Mitchell and Murakami Haruki}

Born and raised in the United Kingdom, David Mitchell moved to Japan in 1994, married a Japanese woman and lived in Hiroshima for eight years. Both his first two novels, Ghostwritten (1999) and Number9dream (2001), are set in Japan. The first novel, Ghostwritten, is constructed with ten chapters, each with a different narrative voice. The novel begins in Okinawa and moves on to Tokyo, and from there to a number of different countries. His second work, Number9dream, on the other hand, is set entirely in Tokyo, and is narrated by a Japanese nineteen-year-old boy, Eiji, from the island of Yakushima. Eiji is an illegitimate child and has never seen his father. After he loses his

19 Sakai, 'Modernity and Its Critique: The Problem of Universalism and Particularism', p. 487.

20 Ibid., p. 495.

21 Ibid., p. 487. 
twin sister, Anju, at the age of eleven, the young man travels to Tokyo to find his father, believing that this would help him find his own identity.

Making use of his experience in Japan, Mitchell in his fiction attempts to overturn the conventional Orientalist perspectives. In an interview about Ghostwritten, Mitchell explained that 'I wanted the book to travel East to West because it reverses the usual direction of Orientalism, and challenges the Eurocentric view of the world map. ${ }^{22}$ In another interview, Mitchell also states:

I have a problem with the way Japan is usually portrayed in the West, as the land of cherry blossoms, geishas, Mt. Fuji, and kamikaze pilots. I wanted to do what Haruki Murakami does, depicting Japan as it is, and finding the beauty in the ugliness. Using Japanese protagonists seems to be a more convincing way to go about that. ${ }^{23}$

Mitchell believes that having a Japanese subjective voice is a first step to go beyond conventional Western descriptions of Japan. This author's adoption of a Japanese narrative voice is quite different from the classical format in which the West speaks for the non-West in a supposedly objective perspective, as the ones I discussed in the first half of the article, in that he voluntarily adopts the perspective of the ethnic and cultural other. The author himself declares that he learnt this approach from Murakami Haruki, and in his works wants to 'depict Japan as it is'. I will come back to my interpretation of Murakami's influence on Mitchell in the next section.

Mitchell also states that his intention is 'to write a bicultural novel, where Japanese perspectives are given an equal weight to Dutch/European perspectives. ${ }^{24}$ When his interviewer mentions the variety of stereotypes about Japan that have become commonplace in the Western collective imaginary, such as 'geisha', 'salaryman', 'Nintendo', 'Aum Shinrikyo' and manga, Mitchell replies:

This plurality of lenses is no bad thing: One view is never enough...these "oven-ready perspectives" are what we fall back on, and they are probably better than nothing, provided that we don't forget that they only scratch the surface. We mustn't tell ourselves, "OK, I've got Japanese/UK/Any country culture sussed: I can stop trying to understand it now". 25

It is interesting that Mitchell calls stereotypical images 'oven-ready perspectives', foregrounding their narrow understanding of Japan. However, his intention is not

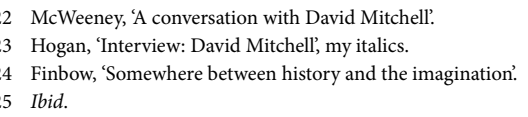


to negate the Western perspective on Japan, but to suggest the importance of having multiple perspectives from both outside and inside Japan.

Ghostwritten incorporates multiple perspectives in its very structure, as each chapter has a different protagonist/narrator. Mitchell locates his characters in different places and looks at each place subjectively, thus taking multiple subjectivities. Such combination of multiple narratives and attempts to challenge cultural stereotypes is another element that Mitchell shares with Murakami Haruki.

\section{Murakami Haruki's influence on David Mitchell (1): 'Japaneseness' and 'un-Japaneseness'}

Murakami Haruki's influence on David Mitchell has been noted by many of his readers, and Mitchell himself has discussed his admiration for Murakami's works in a number of interviews, including this one: 'I had a crush on The Wind-Up Bird Chronicle! Absolutely besotted by it. Love it, love it, love it. ${ }^{26}$ More significantly, Mitchell declares to have learnt important lessons from Murakami, stating that 'Haruki Murakami's novels show how literature can marry popular culture to cook up humour and metaphor. ${ }^{27}$ His own works are replete with references to Murakami's works. For example, the title of his book, Number9dream, which refers to a John Lennon song, \#9Dream, is reminiscent of Murakami's bestseller novel, Norwegian Wood, and its own Beatles reference. The connection is made even stronger when in the novel the protagonist Eiji, who is a big fan of John Lennon, meets Lennon himself in his daydream, and Lennon tells him that “\#9Dream" is a son of "Norwegian Wood". 28

Another element that Number9dream derives from Murakami is its description of a Japan where Western culture has become widespread. Murakami's characters often have a sandwich with coffee for breakfast, cook spaghetti for lunch and drink beer for dinner. Similarly, Mitchell highlights the blend of Western culture and Japanese traditional culture in contemporary Japan. In Number9dream, Eiji drinks a coffee in a café and green tea in his house, smokes American cigarettes, plays soccer, listens to John Lennon, and stays in the futuristic urban city Tokyo. After finishing working at a pizza shop he has his breakfast at McDonald's with a Japanese girl who plays European tunes on the piano. His father sells off a sword that was left as a family heirloom by a kamikaze pilot in his family. In a café, an old man is caught up in a videogame, and in a university a postgraduate student is busy engineering

26 Bradford, 'An interview with David Mitchell'.

27 Mitchell, 'Japan and my Writing.'

28 Mitchell, Number9dream, p. 379. 
computer viruses. A video shop plays 'Titanic' and 'Blade Runner', while yakuza eat sushi, drink sake and enjoy karaoke.

Such lack of 'Japaneseness' has long been a defining feature of Murakami's description of Japan. Elizabeth Devereaux notes that when reading Murakami's novels we should '[f] orget about cherry blossom time, the crags of Fujiyama, tea ceremonies; most especially forget about exquisitely penned haiku.' ${ }^{29}$ However, as Devereaux appreciates the presence of Japanese food in Murakami's novels as a 'last reminder of Japaneseness', Murakami's stories are also exoticised to a degree by his English-speaking audience, and are appreciated for their presentation of Japanese culture in an easily digestible format. In other words, Murakami's peculiar way of using Japaneseness in his novels contributes to his popularity in the West, especially including the United States. In her analysis of the reception of James Clavell's Shogun, Sheila Johnson explains the deeply rooted popularity of traditional Japanese culture in the West. She states that 'the overwhelming impression the book conveys is... perhaps not inaccurate for the historical period being portrayed, but the Western reader is likely to transfer such samurai images directly into the present. ${ }^{30}$ Iwabuchi Kōichi also states that Western readers have long been 'fascinated with some exotic parts of Japan, and lamented the loss of "authentic" Japanese tradition in the process of modernization.' ${ }^{31}$ The inclusion of a certain degree of 'Japaneseness' is therefore important to cater to Western readers' expectations.

As Rebecca Suter indicates, a factor that contributed to the popularity of Murakami's fiction in the English-speaking world is the work of his American translators. She states that thanks to the translators' 'domestication' of 'foreign elements in Murakami's fictions', the texts are '[p] erceived as not-too-Japanese and therefore nonthreatening... [and] are able to escape both the aestheticizing/ feminizing stereotypes and the warrior-like, violent images through which Japanese culture has generally been represented in America'. ${ }^{32}$ Thus this peculiar combination of Japaneseness and un-Japanesness in Murakami's novels functions to reduce a threat of foreignness for Western readers and make the works more palatable to them.

Murakami's popularity in the United States also stems from his choice of topics. According to Michael Fujimoto Keezing, American literary circles tend to appreciate white male authors' dealing with patriarchy and sexism, highlighting American political correctness and the formation of subjectivity in the multicultural society; authors nowadays are hardly published if they write about love or sexuality. Therefore, Keezing

\footnotetext{
Devereaux, 'PW Interviews Murakami Haruki'.

0 Johnson, The Japanese Through American Eyes, pp. 116-17.

1 Iwabuchi, op. cit., p. 49.

2 Suter, op. cit., p. 36.
} 
writes, Murakami Haruki, who often refers to love, is a non-white male and non-American 'Other' for the American literature circles and American readers. He adds that Murakami is obviously one of the great Japanese authors who appeal to contemporary America. ${ }^{33}$

In trying to explain Murakami Haruki’s popularity, Ōtsuka Eiji brings forward the design of his book covers. He explains that when Japanese author Yoshimoto Banana published her book, Kitchen, in the United States, an artist whose works have a similar taste with Sasaki Maki, the Japanese illustrator who often illustrates the Japanese editions of Murakami's books, designed the bill for the advertisement. However, Murakami's books published in the United States display pictures of a kabuki actor and a geisha. Otsuka therefore contends that despite Murakami's attempt to distance himself from other Japanese authors, he is perceived and represented as one of them in the context of the United States. ${ }^{34}$ Thus a certain degree of 'Japaneseness' in Murakami's works supports his popularity.

\section{Donuts and samurai}

The way Murakami treats Western culture in his fiction is also worthy of consideration. His use of Western elements functions to subvert conventional approaches to Japan: a particularly interesting aspect is Murakami's frequent use of katakana words. In this regard, Numano Mitsuyoshi's analysis of a scene from Kaze no uta o kike (Hear the Wind Sing, 1979) is useful:

The young protagonist is offered orange juice [orenji jūsu] and doughnuts [dōnatsu], and katakana [the Japanese syllabary for foreign words] highlights the fact that these are originally foreign products... Of course these things are common in contemporary Japan, yet to have the protagonist eat exclusively this kind of food is not a neutral choice. Furthermore, perhaps nobody does this anymore today, but until a while ago a guest was always offered green tea and wagashi [Japanese sweets]: Murakami voluntarily subverts this pattern. Even later in his life, the protagonist always eats "peanuts, fried potatoes, beer, whisky, wine, cheese, crackers." Even though these things are widespread in Japan today, to put them in a novel takes on a precise meaning. ${ }^{35}$

Suter states that 'Numano Mitsuyoshi rightly notes that the great number of katakana words in Murakami's stories has an anti-realistic effect, making the reader aware of the presence of such words as foreign, alien elements and contributing to the

\footnotetext{
Keezing, 'What Makes Him So Good?: An American Writer's Perspective on Haruki Murakami', pp. 73-4.

4 Ōtsuka, Haruki ron-sabu karuchā to rinri, pp. 3-9.

35 Numano, 'Dōnatsu, Bīru, supagetti- Murakami Haruki to Nihon o meguru sanshö', p. 150, cited in Suter, The Japanization of Modernity, p. 40.
} 
general sense of estrangement created by the texts. ${ }^{36}$ In addition to Murakami's repeated use of katakana words, Suter also points out that the 'anti-realistic effect' of Murakami's stories is obtained through his use of 'the non-abbreviated form of katakana words': 'that are usually contracted, such as rimōto kontorōrā (remote controller) instead of rimokon ("Nyūyōku tankō no higeki," 1983)... They thus undermine the naturalness and referentiality of language, distancing the reader both from the single word and from the text. ${ }^{\prime}{ }^{3}$ Murakami's use of katakana words, in a sense, seems to be a valid approach to portray contemporary Japan 'as it is', that is, in this case, permeated by Western culture and food. It is true that katakana words are broadly used in contemporary Japan, however, Murakami uses them with exceeding frequency and in a marked way that evokes for his readers a sense of unnaturalness in the context of Japanese. It makes readers aware of the existence of foreign words in contemporary Japan.

Similar to Murakami, David Mitchell's use of 'Japaneseness' functions to challenge stereotypes about Japan. In one sense, Mitchell seems to use Japanese traditional elements for a commercial purpose, answering to expectations of the nonJapanese readerships, in the same way as Murakami. Mitchell's use of Japanese traditional elements is quite successful in this respect, and has gained him a broad readership in English-speaking countries as well as prizes and favourable reviews.

For example, in Number9dream the main element that illustrates Japaneseness is the 'samurai spirit'. The novel contains several images of violence and war, mainly centring on stories of yakuza and on the diary of a kamikaze soldier. While this would seem to cater to Western readers' taste for violent images of Japan, it is interesting to examine how Mitchell presents contemporary yakuza in Number9dream. Throughout the novel, yakuza are portrayed as the heirs of samurai spirit in contemporary Japanese society. For example: they complain that Japan allows itself to be so greatly influenced by foreign countries that it disregards its own traditional culture; they lament Japan's lack of self-esteem, noting that ' $[\mathrm{w}]$ hat we lack in Japan is the necessary megalomania' ${ }^{38}$; and they declare that only yakuza still appreciate Japan's own culture and Japan itself. When Eiji asks the yakuza leader Morino for information about his father, he wonders how much he should pay for it. Morino replies: ' $[w]$ hy is it always money, money, money with kids nowadays? Little wonder Japan is becoming this moral and spiritual graveyard'. ${ }^{39}$ Morino's final remark, 'I propose you pay with loyalty' ${ }^{40}$ reflects his intention to follow the samurai code, deploring the present obsession with money in Japan. Thus the

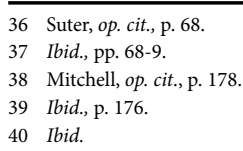


novel initially seems to portray yakuza as the repository of traditional samurai values of loyalty, selflessness, and generosity, responding to Western readers' expectations yet twisting them at the same time.

Mitchell also illustrates the wartime use of this 'samurai spirit'. In the chapter called 'Kaiten', Eiji reads a diary written by his great-uncle who participated in the program of submarine attacks called kaiten during World War Two. Kaiten was one of the kamikaze programs in which submarine pilots were ordered to crash into their target. Eiji, struggling to find his father, receives a letter from a person who calls himself Eiji's grandfather, and asks Eiji to see him in person. When they finally meet, the man gives him a diary composed by his great-uncle during his training in the kaiten program. In the diary, the kamikaze soldier tells of his longing to die for the state and the emperor as a sign of his loyalty to them. As he states that ' $[\mathrm{t}]$ he meaning of my life is to defend the Motherland, ${ }^{41}$ Number9dream illustrates the past samurai spirit in which dying for the mission guarantees a perfect fulfilment in his life.

Although both the stories of yakuza and the diary written by the kamikaze soldier seem to appreciate the samurai spirit, this is put into perspective by the highly graphic descriptions of yakuza violence. The chapter 'Reclaimed Land' describes a yakuza war in which the characters kill members of a rival gang by hitting their heads with a bowling ball. Eiji, forced to stay there, cannot turn away from the gruesome scene:

Down here is chilly and damp. I sneeze. My throat feels tight. Finally we climb to the surface on a dead escalator. "Welcome to Valhalla," says Thor, a thunderbolt in one hand and a bowling ball in the other... In the distance is a suffused glow. This is a bowling alley... Instead of tenpins are three wax human heads. The center head moves. The left head tics. I should not be here. This is a nightmarish mistake. No. This is a sort of interrogation... Lizard bows graciously and selects the heaviest bowling ball. I tell myself this is just a bluff. I should not be here. Lizard steps onto the concourse, and lines up a shot... Lizard steps one, two, and -wham! A fast, uncurving line, my gut knots, I try to wake myself up, or just look away, but when Centerhead screams I look, idiot that I am- and see the worst sight of my life, bar none. RightheadKakizaki, I guess- is no longer recognizable. I want to vomit but nothing comes. Kakizaki is a staved-in cavity of bone and blood. The horn players burst into wild applause. Lefthead is shut down with shock. Centerhead gasps, drowning, spattered with red specks. ${ }^{42}$ 
The yakuza member then forces Eiji to throw a bowling ball. Eiji is reluctant at first, but has to give in when he is told that if he refuses the yakuza will set fire to Eiji's accommodation and inflict a miscarriage upon his landlord's wife, 'I pick up a ball, the lightest. It weighs a lot. No. I cannot do this. This act is not in me... I must miss, but not obviously. I should not be here. I want to apologize to the heads, but how can I?'43

Mitchell also includes other stories about yakuza; for example, they cut the tongues of sax players, draw one litre of blood from a traitor, Daimon, and carry out trafficking of organs of innocent children. Mitchell's description of the yakuza is a far cry from the aestheticisation of samurai spirit presented in the diary of the kaiten soldier. Thus Mitchell's description of the yakuza subverts the readers' exoticising expectations: through his exaggeration of Japan's traditional images, the author provokes readers to question the use of stereotypes of Japan. Through this display of ultra-violence, Mitchell makes his readers aware of their own stereotyping of Japan. If Murakami makes use of Western elements to subvert the conventional images of Japan, Mitchell uses Japanese traditional elements to undermine the same stereotypes.

\section{Murakami Haruki's influence on David Mitchell (2): subjective voices}

Mitchell's use of a Japanese narrator is also problematic: his appropriation of the Other's narrative voice is reminiscent of a long tradition of Western authors' speaking for the non-West, implicitly situating it as subaltern and depriving it of its subjectivity. Mitchell's narrating of Japan simultaneously foregrounds and questions precisely this operation. While an underlying assumption of Orientalist discourse was the West's ability to speak about its Other objectively, Mitchell constantly stresses the importance of taking a subjective stance, something he claims to have learnt from Murakami.

In an intriguing case of flows and contra-flows of cultural influence, Murakami himself claims to have derived his own emphasis on subjective perspective from Raymond Carver, famously referred to as Murakami's favourite author. Murakami explains that Carver 'never wrote his works without using his own deeply personal words... he was a really original writer. It was only him who could describe his worlds and who could control his words. ${ }^{44}$

Murakami, then, emphasises the characters' subjectivity as a basis for their, and the text's, recognition of history. Michael Seats points out 'the dichotomy 
between personal memory and official memory' in Murakami's novels. ${ }^{45}$ Referring to Murakami's Nejimakidori Kuronikuru (The Wind-Up Bird Chronicle, 1994-95) in which Murakami describes Japan's past in Manchuria and its connection with a character's personal memory, Seats explains that this is Murakami's way of recasting history and representing reality. Especially in this case, the juxtaposition performs as the motifs of psychoanalytic and historical dissociation... [which] indicate a repression of the trauma of Japan's encounter with modernity. ${ }^{46}$ In this novel, personal memory takes a crucial role to represent official history. In other works, too, Murakami's characters often speculate on their past personal memory, which is evoked through their contact with official memory. This focus on personal rather than official memory also raised criticism of escapism. However, Murakami's intention is not to ignore history but to emphasise the influential power of personal memory on our epistemological system and the inevitability of our perceiving official memory subjectively.

In a similar way, Murakami asserts the importance of having subjectivity for readers. Jay Rubin in his analysis of Murakami's short story 'Binbō na obasan no hanashi' ('A Poor-Aunt Story', 1980), argues that '[t]he important thing for Murakami is how it feels in the mind of each of us. ${ }^{47}$ Rubin explains that, without any clear explanation by Murakami, the phrase 'poor aunt' offers readers a broad range of interpretation and imagination of 'what it means' or 'who she is'. What 'poor aunt' signifies depends on 'a sense of déjà vu' on the part of the readers, based on their familiarity and their memory. ${ }^{48}$ Murakami leaves the interpretation of his stories to the reader's individual imagination. In other words, Murakami believes that we can perceive things only subjectively, and that establishing a consensual interpretation is pointless. The insufficient information embedded in Murakami's stories allows readers to have their own way of interpretation.

Murakami's belief that subjective perspective is important is echoed in Mitchell's use of a Japanese narrative voice in Number9dream. Mitchell also emphasises the importance of relying on individual taste: ' $[\mathrm{w}]$ hich tools the writer may feel are best suited to the job may depend on the decade or the century, but also on the writer's own tastes, and "inner weather" ${ }^{49}$ Murakami and Mitchell claim that we have no choice but to narrate things subjectively. They acknowledge the invalidity of the use of stereotypes and the impossibility of narrating the Other objectively. Mitchell's attempt to write on Japan with several subjectivities can be a response to a criticism of Number9dream by Darren Waters. Waters claims that:

\footnotetext{
Seats, Murakami Haruki: the simulacrum in contemporary Japanese culture, p. 19.

6 Ibid., p. 320.

Rubin, Murakami Haruki and the Music of Words, p. 60.

8 Ibid.

49 Min, 'The Illusionist's Dream: David Mitchell chats about limb-creeping risk-taking'.
} 
The problem for Mitchell is that the land of the rising sun has become a staid shorthand metaphor for the postmodern world and number9dream finds little original or startling to say about the country or indeed the people who inhabit it... it seems dated, rooted in the 1980s; the decade of Blade Runner and when the word postmodern was fashionably hip in the halls of university campuses and the internet was a secret shared only by those in the know. ${ }^{50}$

While Waters is correct in noting that Mitchell's use of androids and his characters' obsession with video-game and computers is close to the approach of Blade Runner, Number9dream is not merely a parody of such science fiction films. Although Waters points out that Number9dream lacks originality because of its similarity with postmodern works that gained attention in the 1980s, it is my contention that Mitchell's use of plural subjectivities, including a Japanese subjectivity, as a Western author, and his attempt to subvert conventional style to describe Japan are unique approaches.

\section{Conclusion: thinking outside the Chinese Box}

While Number9dream, unlike Ghostwritten, seems to have only one subjective point of view, that of Eiji, the novel is actually constructed with several narrative voices. A number of reviews of Number9dream complain that the readers cannot distinguish among Eiji's real story, his dream/daydream/imagination, and his memory. Interestingly, Eiji's narrative voice in each of these dimensions is slightly different. Compared with Eiji in the main plot, Eiji in his dream and imagination is much bolder, to the point of showing an extremely violent personality and killing the lawyer who, Eiji believes, keeps his father's information from him. On the other hand, Eiji in his memory at age eleven has a timid personality and was often defeated in competitions with his sister. Similar to Murakami, Mitchell does not provide a clear answer as to what is actually happening, and does not clarify which Eiji is the 'real one' in the novel. In this respect, we can say that in Number9dream Mitchell also employs multiple subjectivities, by showing multiple dimensions of Eiji.

In light of this, Murakami states in the interview with Ōga that having multiple subjectivities (shiten no jūsōka) is necessary to write novels and, in this regard, the style adopted in Fyodor Dostoevsky's The Brothers Karamazov is the ideal form. ${ }^{51}$ Mitchell's use of multiple subjectivities in Ghostwritten and Number9dream is reminiscent of Dostoevsky's writing style in which he lets each character have a long speech to illustrate what happens in the novel.

50 Waters, 'Number9dream fails to rouse'.

51 Ōga, 'E-mēru intabyū: kotoba to iu hageshii buki', pp. 19-20. 
The above also reminds us of Murakami's description of reality as having a 'Chinese box-like structure' in Yakusoku sareta basho de - Andäguraundo 2 (The Place That Was Promised - Underground 2), a collection of interviews with members of the Aum Shinrikyō cult after the Tokyo sarin gas attack of 1995. In the afterword of the book, Murakami states:

I think that we see the structure of the world fundamentally as something like Chinese boxes. Inside a box there is another box, and inside that another one, and so on. I think that we unconsciously perceive the existence of another world one level outside the world we are seeing now, or one level inside it... But the people in Aum, although they say that they are desperately looking for a "different world," in fact have a very narrow vision, and see the world as exceedingly linear and simple... They are unable to see beyond one of the boxes. ${ }^{52}$

If reality is structured like a set of Chinese boxes, the implication is that we need to have multiple perspectives to examine it. To depend on a single perspective never allows people to have a broad vision. Staying inside a small box, they do not realise the presence of the outside world. Murakami adds to his statement in Yakusoku sareta basho $d e$ that 'we have to prove the box's limitation [to the members of Aum]. ${ }^{53}$ The members of Aum heavily relied on the story that the cult presented them with, and conceived it as the only truth. Cultural stereotyping is similarly limiting people's perception of reality and ignoring the multiplicity of reality.

Eleven years after publishing Yakusoku sareta basho de, Murakami returned to writing about the Aum cult in 1Q84<ichi-kew-hachi-yon>. In this novel, the author once again relies on multiple subjectivities and lets each character speak its own story in detail. In an interview, Murakami explains that in the novel he 'carefully portrayed each character, giving a name to almost all the characters, in order to arouse a sense that any character could have been ourselves. ${ }^{54}$ In another interview, Murakami also remarks, 'it is not that I wanted to write about Aum itself, but I wanted to describe the world of Aum, which has another kind of reality in it, as if it is "a box within another box" ("hako no naka no hako")'.55 His attempt to describe a Chinese-box-structured reality is therefore quite central to his role as a writer.

This gives us further insight into David Mitchell's purported aim of describing Japan 'as it is' in the same way as Murakami. In his novels, Mitchell first adopts the subjective position of the cultural and ethnic Other, writing through a Japanese narrative voice, in

\footnotetext{
Murakami, Yakusoku sareta basho de, p. 232, cited in Suter, Japanization of Modernity, p. 112.

3 Ibid., p. 233, my translation.

4 Murakami, “1Q84” e no 30 nen, Murakami Haruki shi Intabyü', my translation.

55 Murakami, 'Murakami Haruki shi: “1Q84” o kataru: Tandoku Intabyū (2) Kojin o Nijū ni Assatsu”, my translation.
} 
order to cater to Western readers' desires for Japaneseness, similar to how Murakami includes a certain degree of 'Japanese essence' for his foreign readers. However, Mitchell then proceeds to subvert the readers' expectations he has built, through his description of the ultra-violence of yakuza, while Murakami subverts them through his display of Western pop culture elements and through his use of katakana words. Such subversion of the readers' expectations ultimately leads to a subversion of their cultural stereotypes. For both authors, the principal problem with stereotypes is that they present us with a unitary and linear vision of reality, while reality is constituted, as Murakami claims, by multiple layers, like 'Chinese boxes.' Furthermore, cultural stereotypes create the impression that we can perceive, and speak for, the Other objectively, as a long tradition of Orientalist discourse testifies to. David Mitchell, on the contrary, acknowledges the fact that we can see things only subjectively, and thus chooses to write with a Japanese narrative voice in order to incorporate and deconstruct stereotypical representations of Japan. In doing this, he goes beyond both classical Orientalism and techno-Orientalism; arguably this is the most important lesson that this author learned from Murakami Haruki.

\section{References}

Benedict, R., The Chrysanthemum and the Sword (Boston: Houghton Mifflin, 1946).

Bradford, S., 'An interview with David Mitchell', The Lumiere Reader, 2 April 2008. Retrieved 6 June 2009, from http:// lumiere.net.nz/reader/arts.php/item/1611.

Devereaux, E., 'PW Interviews Murakami Haruki', Publisher's Weekly, (21 September 1991), pp. 1-12.

Iwabuchi, K., 'Complicit exoticism: Japan and its other', The Australian Journal of Media \& Culture, vol. 8, no. 2, (1994), pp. 49-82.

Finbow, S., 'Somewhere between history and the imagination', The Japan Times. Retrieved 24 June 2007, from http:// search.japantimes.co.jp/cgi-bin/fb20070624a1.html.

Hogan, R., 'Interview: David Mitchell', Indie Bound. Retrieved 28 May 2009, from http://www.indiebound.org/authorinterviews/mitchelldavid.

Johnson, S. K., The Japanese through American eyes (California: Stanford UP, 1988).

Keezing, M. F., 'What Makes Him So Good?: An American Writer's Perspective on Haruki Murakami'. Translated by Ōgushi, H., Yuriika vol. 32, no. 4 (2000), pp. 72-75.

McWeeney, C., 'A conversation with David Mitchell', Bold Type: Randomhouse. com. Retrieved 28 May 2009, from http://www.randomhouse.com/boldtype/1100/mitchell/interview.html.

Minear, R. H., 'Orientalism and the study of Japan', The Journal of Asian Studies, vol. 39, no. 3 (1980), pp. 507-517.

Min, T. H., 'The Illusionist's Dream: David Mitchell chats about limb-creeping risk-taking', Quarterly Literary Review Singapore, vol. 1, no. 2, (Jan 2002). Retrieved 28 May 2009, from http://www.qlrs.com/issues/jan2002/ interviews/dmitchell.html. 
Mitchell, D., Ghostwritten (London: Hodder and Stoughton, 1999).

Mitchell, D., 'Japan and my Writing', Bold Type: Randomhouse. com. Retrieved 28 May 2009, from http://www. randomhouse.com/boldtype/1100/mitchell/essay.html.

Mitchell, D., Number9dream (New York: Random House, 2003).

Morley, D. and Robins, K., 'Techno-Orientalism: Futures, Foreigners and Phobias', New Formations, vol. 16, (1992), pp. 136-156.

Murakami, H., “1Q84” e no 30 nen, Murakami Haruki shi Intabyū' ('30 years up to "1Q84”, Interview with Murakami Haruki’) Yomiuri Online, Yomiuri Shinbun, (16 June 2009). Retrieved 1 October 2009, from http://www. yomiuri.co.jp/book/news/20090616bk02.htm.

Murakami, H., 'Murakami Haruki shi: '1Q84' o kataru, Tandoku Intabyū (2) Kojin o Nijū ni Assatsu' ('The second interview with Murakami Haruki on “1Q84”') Mainichi jp, Mainichi Shinbun (17 September 2009). Retrieved 1 October 2009, from http://mainichi.jp/enta/book/news/20090917mog00m040002000c.html.

Murakami, H., 'Raymond Carver no hayasugita shi' ('Raymond Carver's early death') Shinchō, vol. 84, no. 4 (April 1989), pp. 244-9.

Murakami, H., Yakusoku sareta basho de - Andāguraundo 2 (Tokyo: Bungei shunjū, 1998).

Numano, M., 'Dōnatsu, Bīru, supagetti - Murakami Haruki to Nihon o meguru sanshō' ('Doughnuts, Beer, Spaghetti Three Chapters on Murakami Haruki and Japan') Yuriika (Special Issue), (June 1989), pp. 144-57.

Ōga, K., 'E-mēru intabyū: kotoba to iu hageshii buki' ('E-mail Interview: Words as Fierce Weapons') Yuriika (March 2000), pp. 8-27.

Ōtsuka, E., Haruki ron - sabu karuchā to rinri (On Murakami Haruki - subculture and ethics), (Tokyo: Wakakusa Shobō, 2006).

Reich, R., 'The rise of techno-nationalism; in the emerging debate about how to restore America's technological preeminence we are misconstruing the problem and advancing the wrong solutions', The Atlantic, (May 1987), pp. 62-70.

Revell, L., 'Nihonjinron: Made in the USA', in Hammond, P. (ed.), Cultural Difference, Media Memories: AngloAmerican Images of Japan (London and Washington: Cassell, 1997), pp. 51-81.

Rubin, J., Haruki Murakami and the Music of Words (London: Vintage Books, 2002).

Said, E., Orientalism (London: Routledge, 1978).

Sakai, N., 'Modernity and Its Critique: The Problem of Universalism and Particularism', South Atlantic Quarterly, vol. 87, no. 3 (1988), pp. 475-504.

Seats, M., Murakami Haruki: the simulacrum in contemporary Japanese culture (Lanham, Md.: Lexington Books, c2006).

Suter, R., The Japanization of Modernity, Murakami Haruki between Japan and the United States (Cambridge: Harvard UP, 2008).

Waters, D., 'Number9dream fails to rouse', BBC News Online, 12 October 2001. Retrieved 6 June 2009, from http://news. bbc.co.uk/2/hi/entertainment/1586448.stm.

Yoshimoto, M., 'The Postmodern and Mass Images in Japan', Public Culture, vol. 1, no. 2 (1989), pp. 8-18. 